\title{
Distribution extension and sympatric occurrence of Gracilinanus agilis and G. microtarsus (Didelphimorphia, Didelphidae), with cytogenetic notes
}

\author{
Lena Geise ${ }^{1,3}$ \& Diego Astúa ${ }^{2}$ \\ ${ }^{1}$ Laboratório de Mastozoologia, Departamento de Zoologia, Instituto de Biologia, \\ Universidade do Estado do Rio de Janeiro - UERJ, \\ Rua São Francisco Xavier, 524, Maracanã, CEP 20550-900, Rio de Janeiro, RJ, Brazil \\ ${ }^{2}$ Laboratório de Mastozoologia, Departamento de Zoologia, Universidade Federal de Pernambuco - UFPE, \\ Av. Prof. Moraes Rego, s/n, Cidade Universitária, CEP 50670-420, Recife, PE, Brazil \\ e-mail: diegoastua@ufpe.br \\ ${ }^{3}$ Corresponding Author: Lena Geise, e-mail: lenageise@gmail.com
}

GEISE, L. \& ASTÚA, D. Distribution extension and sympatric occurrence of Gracilinanus agilis and G. microtarsus (Didelphimorphia, Didelphidae), with cytogenetic notes. Biota Neotrop., 9(4): http://www. biotaneotropica.org.br/v9n4/en/abstract?short-communication+bn01909042009.

\begin{abstract}
Gracilinanus microtarsus, from the Atlantic Forest and G. agilis, widespread in central Brazil in the Cerrado and in the northeastern Caatinga are two small Neotropical arboreal opossum species not frequently recorded in simpatry. Here we report eight G. agilis specimens from three localities and 17 G. microtarsus, from 10 localities, all in Minas Gerais, Rio de Janeiro and Bahia states. Species proper identification followed diagnostic characters as appearance of dorsum pelage, ocular-mark, ears and tail lengths and size proportion of the posteromedial vacuities in cranium. Chromosomes in metaphases of five specimens were obtained for both species. Our records extend the previous known geographical distribution of G. microtarsus to Chapada Diamantina, in Bahia State and report the occurrence of both species in simpatry. G. microtarsus, in coastal area, was captured in dense ombrophilous and in semideciduous forests, in deciduous seasonal forest and Cerradão in Chapada Diamantina. G. agilis was recorded in gallery forests of Cerrado and very green and dense bush formation of Caatinga. Autosomal complement showed the same diploid and autosomal number already described for both species $(2 \mathrm{n}=14, \mathrm{NA}=24)$. Measurements are according to those given in literature and pelage characteristics were useful for the correct species identification. Here we report both G. agilis, described to be endemic to the Cerrado/Caatinga, in opposite to G. microtarsus, considered to be endemic to Atlantic Forest occurring in simpatry in two localities of the Cerrado. Such results indicates that long term trapping effort are necessary to a better definition of species taxonomy, distribution patterns along time and comprehensive understanding how anthropic environmental changes can be interfering in their evolutionary history.
\end{abstract}

Keywords: South America, neotropical marsupials, karyotypes, habitat use.

GEISE, L. \& ASTÚA, D. Extensão da distribuição e ocorrência em simpatria de Gracilinanus agilis e G. microtarsus (Didelphimorphia, Didelphidae) com notas citogenéticas. Biota Neotrop., 9(4): http://www. biotaneotropica.org.br/v9n4/pt/abstract?short-communication+bn01909042009.

Resumo: Gracilinanus microtarsus, da Mata Atlântica e G. agilis, amplamente distribuído no Brasil central, tanto no Cerrado como na Caatinga são duas pequenas espécies de cuícas arbóreas. As duas espécies são raramente registradas em simpatria. Aqui registramos oito espécimes de G. agilis coletadas em três localidades e 17 G. microtarsus, de dez localidades, todas nos estados de Minas Gerais, Rio de Janeiro e Bahia. A correta identificação baseou-se nos caracteres diagnósticos como aparência da pelagem dorsal, marca escura na região óptica, comprimentos da orelha e cauda, bem como a proporção do tamanho das vacuidades posteromediais do crânio. Cromossomos metafásicos de cinco indivíduos foram obtidos. Nossos registros aumentam a distribuição geográfica previamente conhecida de G. microtarsus para a Chapada Diamantina, no estado da Bahia, e reporta a ocorrência de simpatria. G. microtarsus, na área costeira, foi capturado em florestas ombrófila densa e semidecidual em floresta estacional decidual e Cerradão na Chapada Diamantina. G. agilis foi registrado em matas de galeria do Cerrado, e formações densas de vegetação arbustiva verde na Caatinga. O complemento autossômico mostrou os mesmos números diplóides e autossômicos já registrados para as duas espécies $(2 \mathrm{n}=14, \mathrm{NA}=24)$. Medidas corpóreas estão de acordo com a literatura, e as características de pelagem foram ferramentas úteis para a correta identificação das espécies. Aqui registramos G. agilis, descrita como sendo uma espécie endêmica do Cerrado e da Caatinga, em oposição a G. microtarsus, considerada como endêmica da Mata Atlântica ocorrendo em simpatria em duas localidades do Cerrado. Tais resultados indicam que esforços continuados de coleta são necessários para uma melhor definição da taxonomia das espécies, dos padrões de distribuição ao longo do tempo e uma melhor compreensão de como as mudanças ambientais antrópicas estão interferindo em suas historias evolutivas.

Palavras-chave: América do Sul, marsupiais neotropicais, cariótipos, uso de habitat. 


\section{Introduction}

The small Neotropical arboreal opossum species of the genus Gracilinanus Gardner \& Creighton 1989 currently include six species (Gardner 2007, Voss \& Jansa 2009). Of these, only G. agilis (Burmeister 1854) and G. microtarsus (Wagner 1842) are present in the central, southern and southeastern regions of Brazil, the remaining species being either Amazonian or with no records for Brazil (Gardner 2007). The distribution in South America has been reviewed by Patton \& Costa (2003), and updated during the IUCN Global Mammal Assessment (Brito et al. 2008), yielding range maps similar, though not identical, to those presented by Gardner (2007) based on marginal localities. In the Atlantic Forest, G. microtarsus occurs from Paraná state up to northern Rio de Janeiro, southern Minas Gerais and Bahia states, with its type locality in Ipanema (São Paulo state), while G. agilis is widespread in central Brazil, including dry areas in the northeastern Caatinga (Figure 1) (Costa et al. 2003, Patton $\&$ Costa 2003, Pardini 2004). A possible contact zone between these two species was registered near the type locality of G. agilis, Lagoa Santa, Minas Gerais (Costa et al. 2003). Although current distribution maps indicate an overlap of their distribution ranges (Figure 1), actual records of sympatry are scarce, even in surveys of intense sampling effort (Carmignotto 2004, Gardner 2007).

These small marsupials, with arboreal adaptations such as long digits in both fore and hind feet and long and prehensile tail (Fonseca \& Kierulff 1989, Emmons \& Feer 1997, Gardner 2007), use higher layers in the forest, although they have been captured in the sub-forest or on the ground (Vieira 2006). As all other small opossums, they feed on small invertebrates and fruits (Santori \& Astúa de Moraes 2006), and females do not present a pouch, with young remaining only a short period attached to the nipples and being left early in their nests (Monteiro-Filho \& Cáceres 2006). As only few specimens are usually trapped during surveys, Fernandez \& Pires (2006) consider them as being an uncommon species.

The main goal of the present paper was to update and extend the distribution and report the use of Brazilian biomes by G. microtarsus and G. agilis, considered to be exclusive to the Atlantic Forest and to the Cerrado and Caatinga, and present karyological data on these specimens.

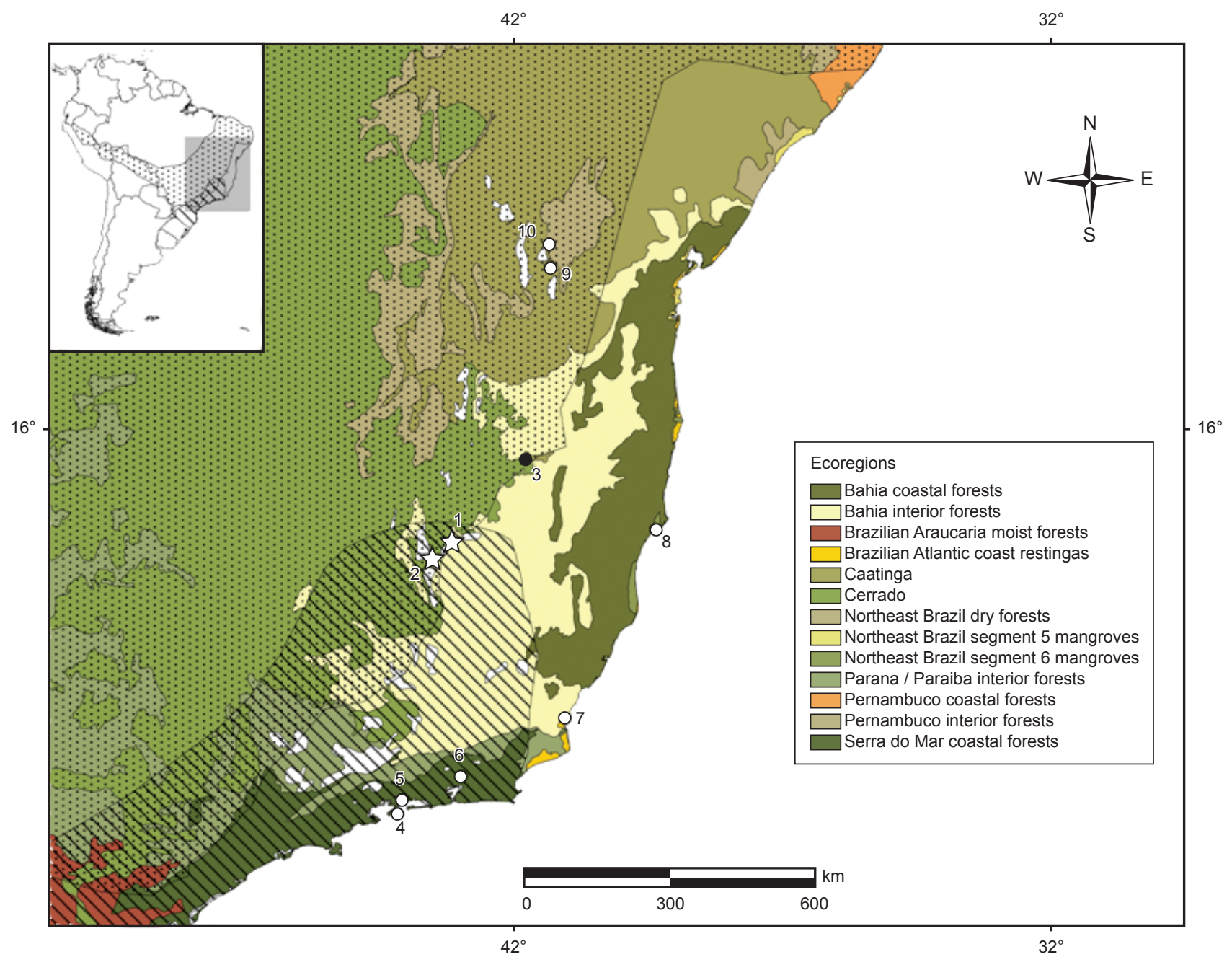

Figure 1. Previously known distributions of Gracilinanus agilis (dotted) and G. microtarsus (hatched), according to IUCN et al. (2008), new records presented here (1-10) and ecorregions, according to Olson et al., (2001). ( $\mathrm{O}=$ G. microtarsus; $\bullet=$ G. agilis; $\overrightarrow{\mathrm{s}}=$ sympatry). Number of localities according to Table 1.

Figura 1. Distribuições previamente conhecidas de Gracilinanus agilis (pontilhado) e G. microtarsus (hachurado), de acordo com IUCN et al. (2008), novos registros (1-10) e ecorregiões de acordo com Olson et al (2001). ( $\mathrm{O}=$ G. microtarsus; $\bullet=$ G. agilis; ì = simpatria). Número das localidades de acordo com a Tabela 1. 


\section{Material and Methods}

The specimens were captured using pitfall traps with drift fences and live traps $\left(\right.$ Sherman $\left.^{\circledR}\right)$ installed on the ground and in trees (Table 1). Coordinates and altitude were obtained at each capture line with a handheld Global Positioning System receiver (Garmin GPSIII ${ }^{\circledR}$ ). Vegetation types follow IBGE, Morellato \& Haddad (2000) and field observation made by the authors.

Chromosomes in metaphases of five specimens were obtained with in vitro culture (culture of bone marrow grown in Dulbecco's MEM with $10 \%$ fetal bovine serum and colchicine). Conventional staining with $5 \%$ Giemsa was used to observe diploid (2n) and autosomal (AN, excluding sexual chromosomes) numbers and chromosome morphology. This analysis was carried out using an optic photomicroscope (Hund Wetzlar - H500 LL HP100 with a digital Canon Power Shot A640 camera).

Voucher specimens were prepared as skins, skulls and partial skeletons and were deposited in the mammal collections in the Museu de Zoologia da Universidade de São Paulo, São Paulo and Museu Nacional da Universidade Federal do Rio de Janeiro, Rio de Janeiro. Five standard external measurements (in millimeters) and weight (in grams) were recorded during preparation.

\section{Results and Discussion}

In this study we registered eight $G$. agilis specimens from three localities and $17 \mathrm{G}$. microtarsus from 10 localities (Figure 1 and Table 1). Species identification followed diagnostic characters from Costa et al. (2003): appearance of dorsal pelage, being grizzly grayish-brown in G. agilis and uniform reddish-brown in G. microtarsus; spreading of gray-based hairs across the ventral area, occurring throughout, except from upper chest and chin in G. agilis and variable in G. microtarsus (Figure 2); ocular-mark thin, small and not extending to nose and ears in G. agilis and broad, large and extending to nose and ears in G. microtarsus (Figure 3); ears larger than $21 \mathrm{~mm}$ in G. agilis and smaller than $21 \mathrm{~mm}$ in G. microtarsus; and tail smaller (than $140 \mathrm{~mm}$ ) in G. agilis and longer in $G$. microtarsus. Finally, larger posteromedial vacuities in cranium were observed in G. agilis, being smaller in G. microtarsus (Figure 4).

The occurrence of G. microtarsus in the Chapada Diamantina, in Bahia State (Figure 1), extends the previous known geographical distribution to the north (Pardini 2004, Pereira \& Geise 2007). Two other localities fall outside the previously known distribution, extending it eastwards. These are Mata do Carvão, São Francisco de Itabapoana, RJ, and Helvécia, BA, the latter representing an extension of its distribution to the coastal Atlan-

Table 1. Collecting localities and specimens discussed on the text. MN - Museu Nacional do Rio de Janeiro, Rio de Janeiro; MZUSP - Museu de Zoologia da USP. Numbers in parenthesis after locality name correspond to the same numbered localities on the map (Figure 1). Coordinates and altitudes obtained by the authors. $\mathrm{Ce}=$ Cerrado, $\mathrm{Ca}=$ Caatinga, $\mathrm{AF}=$ Atlantic Forest, $\mathrm{S}=$ Sherman, $\mathrm{P}=$ Pitfall, $\mathrm{G}=$ ground, $\mathrm{T}=$ Tree, $*$ Karyotyped specimens.

Tabela 1. Localidades de coleta e espécimes discutidos no texto. Museu Nacional do Rio de Janeiro, Rio de Janeiro; MZUSP - Museu de Zoologia da USP. Números entre parenteses depois do nome da localidade correspondem ao mesmo número das localidades no mapa da Figura 1. Coordenadas e altitudes obtidas pelos autores. $\mathrm{Ce}=$ Cerrado, $\mathrm{Ca}=$ Caatinga, $\mathrm{AF}=$ Floresta Atlântica, $\mathrm{S}=$ Sherman, $\mathrm{P}=$ Pitfall, $\mathrm{G}=$ chão, $\mathrm{T}=$ árvore, $*$ Espécimes cariotipados .

\begin{tabular}{|c|c|c|c|c|c|c|c|c|c|}
\hline Species & $\begin{array}{c}\text { Specimen } \\
\text { number }\end{array}$ & Sex & $\begin{array}{l}\text { Locality } \\
\text { number }\end{array}$ & Locality & Coordinates & $\begin{array}{l}\text { Altitude } \\
\text { (m) }\end{array}$ & $\begin{array}{c}\text { Biome / } \\
\text { Vegetation }\end{array}$ & Trap & Capture \\
\hline
\end{tabular}

G. agilis

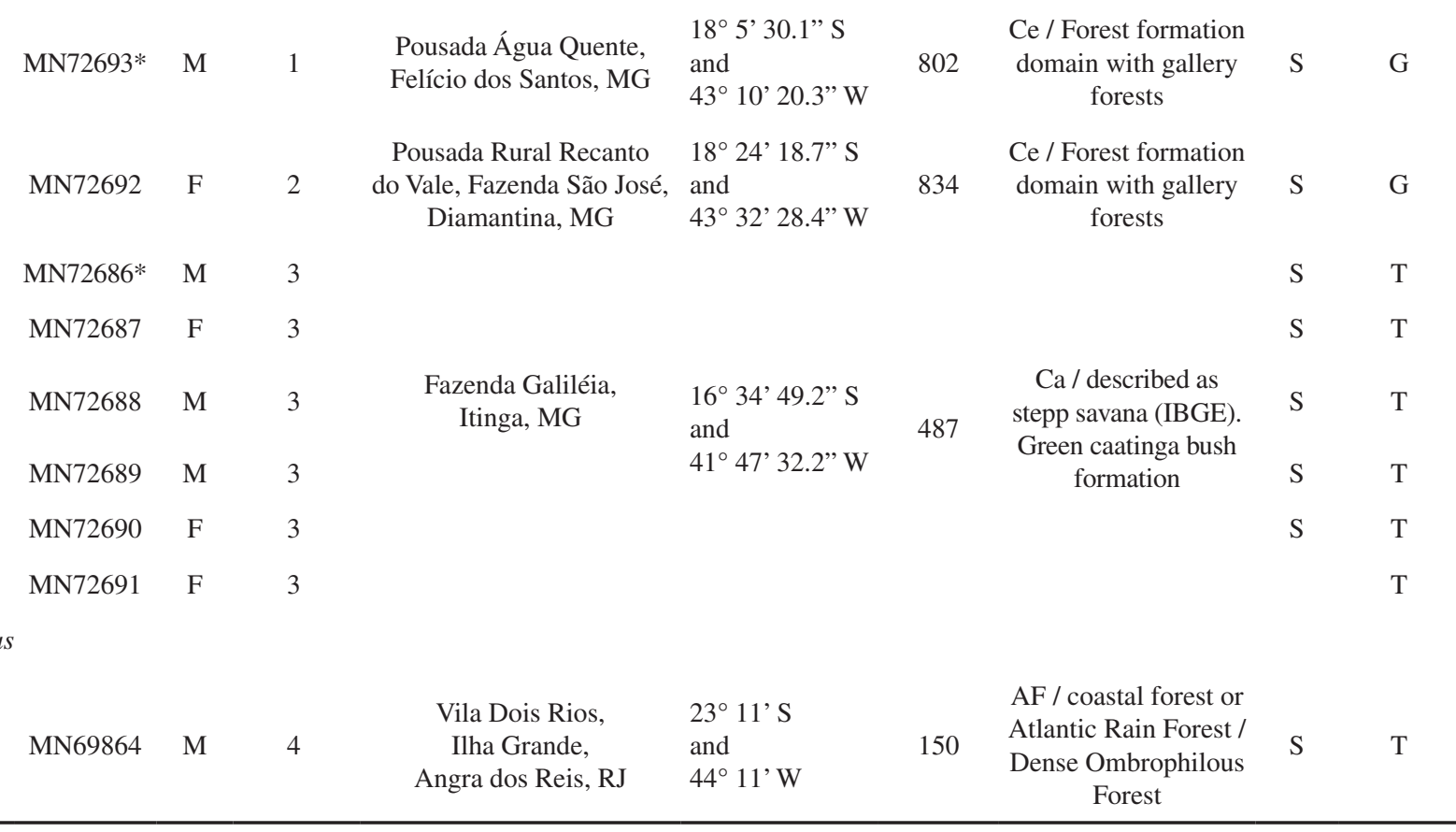


Table 1. Continued...

Tabela 1. Continuação...

\begin{tabular}{|c|c|c|c|c|c|c|c|c|c|}
\hline Species & $\begin{array}{l}\text { Specimen } \\
\text { number }\end{array}$ & Sex & $\begin{array}{l}\text { Locality } \\
\text { number }\end{array}$ & Locality & Coordinates & $\begin{array}{l}\text { Altitude } \\
\text { (m) }\end{array}$ & $\begin{array}{c}\text { Biome / } \\
\text { Vegetation }\end{array}$ & Trap & Capture \\
\hline & MN72694 & M & 5 & \multirow{6}{*}{$\begin{array}{l}\text { Fazenda Bom Jardim, } \\
\text { Mangaratiba, RJ }\end{array}$} & \multirow{6}{*}{$\begin{array}{l}22^{\circ} 55^{\prime} 12.1^{\prime \prime} \mathrm{S} \\
\text { and } \\
44^{\circ} 06^{\prime} 32.3 ” \mathrm{~W}\end{array}$} & \multirow{6}{*}{31} & \multirow{5}{*}{$\begin{array}{c}\text { AF / coastal forest or } \\
\text { Atlantic Rain Forest / } \\
\text { Dense Ombrophilous } \\
\text { Forest }\end{array}$} & $\mathrm{P}$ & $\mathrm{G}$ \\
\hline & MN72695 & I & 5 & & & & & $\mathrm{P}$ & $\mathrm{G}$ \\
\hline & MN72696 & M & 5 & & & & & $\mathrm{P}$ & $\mathrm{G}$ \\
\hline & MN72697 & M & 5 & & & & & $\mathrm{P}$ & $\mathrm{G}$ \\
\hline & MN72698 & I & 5 & & & & & $\mathrm{P}$ & $\mathrm{G}$ \\
\hline & MN72699 & M & 5 & & & & & $\mathrm{P}$ & $\mathrm{G}$ \\
\hline & MN71604 & M & 6 & $\begin{array}{c}\text { Garrafão, } \\
\text { Guapimirim, RJ }\end{array}$ & $\begin{array}{l}22^{\circ} 29^{\prime} \mathrm{S} \\
\text { and } \\
43^{\circ} 00^{\prime \prime} \mathrm{W}\end{array}$ & 700 & $\begin{array}{c}\text { AF / coastal forest or } \\
\text { Atlantic Rain Forest / } \\
\text { Dense Ombrophilous } \\
\text { Forest }\end{array}$ & $\mathrm{S}$ & $\mathrm{T}$ \\
\hline & MN69886 & M & 7 & $\begin{array}{l}\text { Mata do Carvão, } \\
\text { São Francisco } \\
\text { de Itabapoana, RJ }\end{array}$ & $\begin{array}{l}21^{\circ} 24^{\prime} \mathrm{S} \\
\text { and } \\
41^{\circ} 04^{\prime} \mathrm{W}\end{array}$ & 50 & $\begin{array}{l}\text { AF / coastal forest or } \\
\text { Atlantic Rain Forest / } \\
\text { Semidecidous Forest }\end{array}$ & $\mathrm{S}$ & $\mathrm{T}$ \\
\hline & MN72701* & M & 1 & $\begin{array}{l}\text { Pousada Água Quente, } \\
\text { Felício dos Santos, MG }\end{array}$ & $\begin{array}{l}18^{\circ} 05^{\prime} 32.5^{\prime \prime} \mathrm{S} \\
\text { and } \\
43^{\circ} 10^{\prime} 26.2^{\prime \prime} \mathrm{W}\end{array}$ & 788 & $\begin{array}{l}\text { Ce / Forest formation } \\
\text { domain with gallery } \\
\text { forests }\end{array}$ & $\mathrm{S}$ & $\mathrm{G}$ \\
\hline & MN72702* & $\mathrm{F}$ & 2 & $\begin{array}{c}\text { Pousada Rural Recanto } \\
\text { do Vale, Fazenda São José, } \\
\text { Diamantina, MG }\end{array}$ & $\begin{array}{l}18^{\circ} 23^{\prime} 53.1^{\prime \prime} \mathrm{S} \\
\text { and } \\
43^{\circ} 32^{\prime} 31.4^{\prime \prime} \mathrm{W}\end{array}$ & 873 & $\begin{array}{l}\text { Ce / Forest formation } \\
\text { domain with gallery } \\
\text { forests }\end{array}$ & S & $\mathrm{T}$ \\
\hline & MN48008 & M & 8 & $\begin{array}{c}\text { Helvécia, } \\
\text { Nova Viçosa, BA }\end{array}$ & $\begin{array}{l}17^{\circ} 53^{\prime} \mathrm{S} \\
\text { and } \\
39^{\circ} 22^{\prime} \mathrm{W}\end{array}$ & 52 & $\begin{array}{c}\text { AF / coastal forest or } \\
\text { Atlantic Rain Forest / } \\
\text { Dense Ombrophilous } \\
\text { Forest }\end{array}$ & & \\
\hline & MN72700* & $\mathrm{F}$ & 9 & $\begin{array}{l}\text { Chapada Diamantina, } \\
\text { Mata do Zé Leandro, } \\
\text { Projeto Sempre Viva, } \\
\text { Mucugê, BA }\end{array}$ & $\begin{array}{l}13^{\circ} 00^{\prime} 16^{\prime \prime} \mathrm{S} \\
\text { and } \\
41^{\circ} 20^{\prime} 27.5^{\prime \prime} \mathrm{W}\end{array}$ & 980 & Ce / Cerradão & $\mathrm{S}$ & $\mathrm{G}$ \\
\hline & MZ33832 & M & 10 & $\begin{array}{l}\text { Chapada Diamantina, } \\
\text { Remanso, Lençóis, BA }\end{array}$ & $\begin{array}{l}12^{\circ} 34^{\prime} 16.7^{\prime \prime} \mathrm{S} \\
\text { and } \\
41^{\circ} 21^{\prime} 8.2^{\prime \prime} \mathrm{W}\end{array}$ & 560 & $\begin{array}{l}\text { AF / Deciduous } \\
\text { Seasonal Forest }\end{array}$ & $\mathrm{P}$ & $\mathrm{G}$ \\
\hline
\end{tabular}

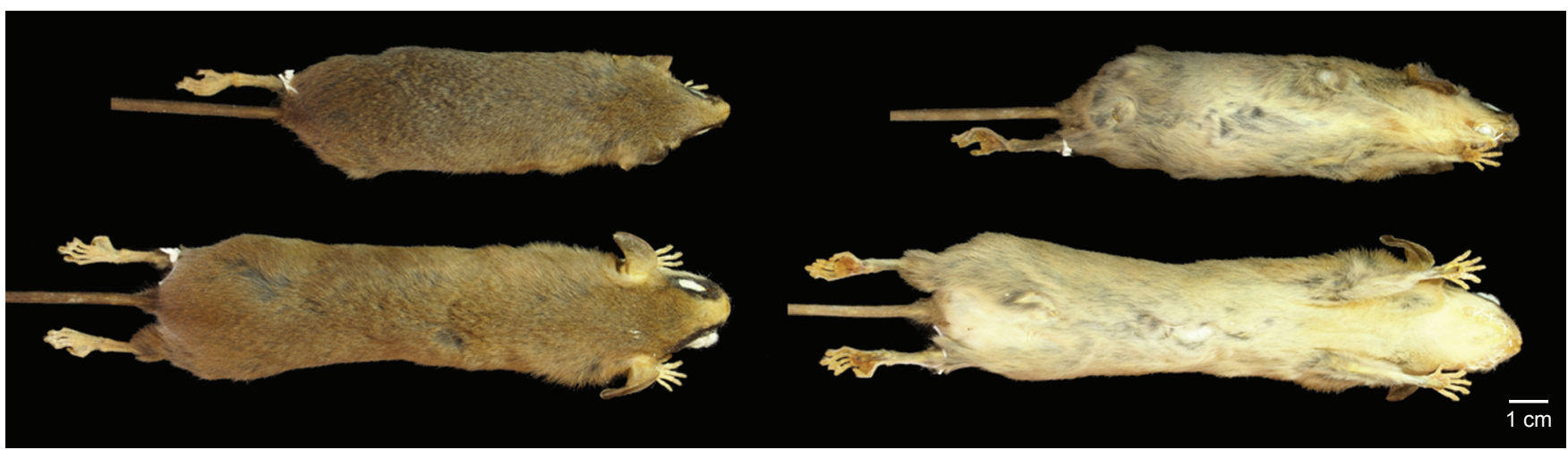

Figure 2. Dorsal (right) and ventral (left) views of selected stuffed study skins of Gracilinanus agilis (upper specimen) specimen and G. microtarsus (lower specimen): MN72689, from Itinga (locality 3) and MN72700, from Mucugê (locality 9), respectively. Locality numbers in parenthesis are according to Table 1.

Figura 2. Vistas dorsal (direita) e ventral (esquerda) de espécimes taxidermizados de Gracilinanus agilis (espécime superior) e G. microtarsus (espécime inferior): MN72689, de Itinga (localidade 3) e MN72700, de Mucugê (localidade 9), respectivamente. Número das localidades entre parênteses estão de acordo com a Tabela 1. 


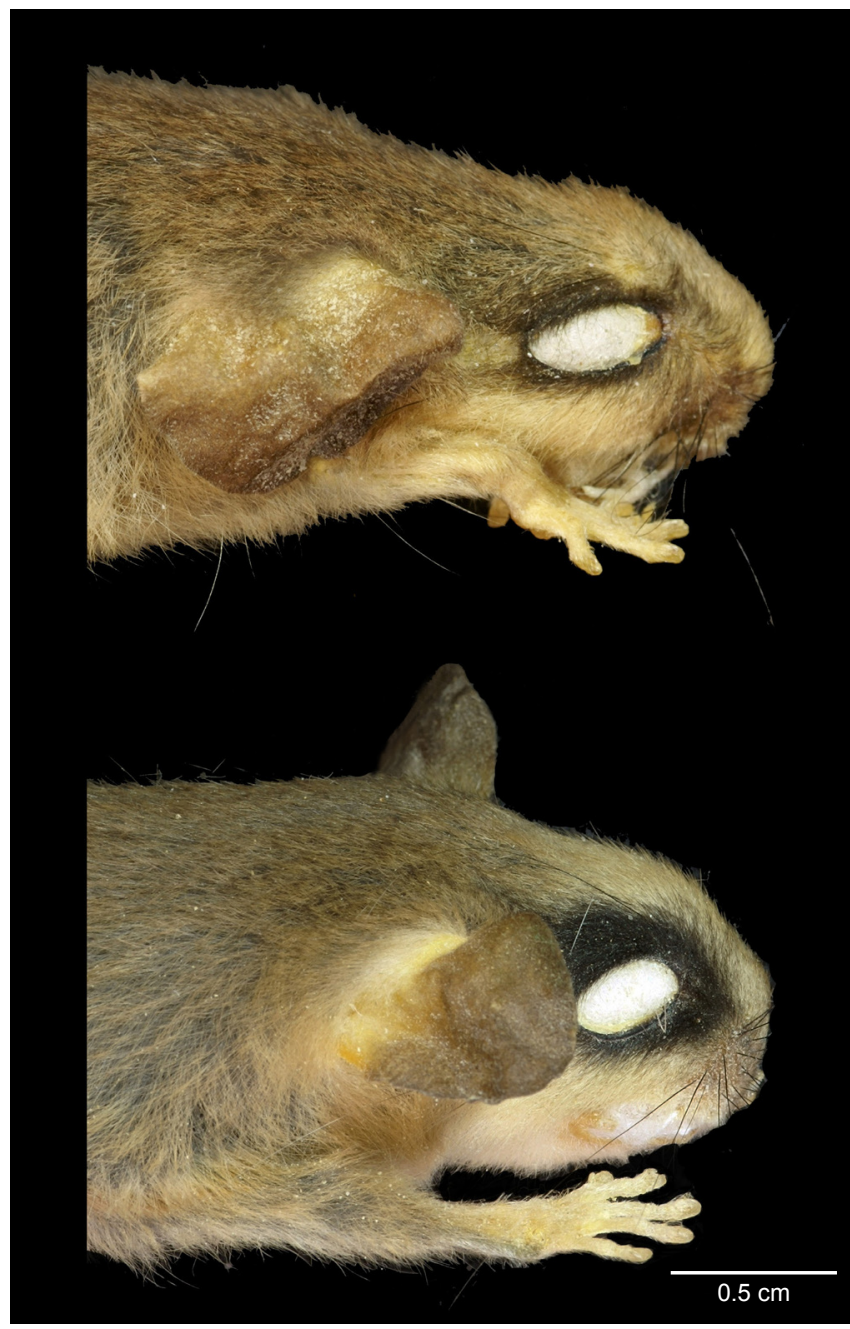

Figure 3. Right lateral views of the stuffed study skins of Gracilinanus agilis (MN72689, upper specimen, from Itinga, locality 3) and G. microtarsus (MN72702, lower specimen, from Diamantina, locality 2). Locality numbers in parenthesis are according to Table 1.

Figura 3. Vista da parte lateral direita de espécimes taxidermizados de Gracilinanus agilis (MN72689, espécime superior, de Itinga, localidade 3) e G. microtarsus (MN72702, espécime inferior, de Diamantina, localidade 2). Número das localidades entre parênteses estão de acordo com a Tabela 1.

tic Forest of Bahia (Table 1). We also report the occurrence of G. microtarsus and G. agilis in sympatry in localities 1 (Pousada Água Quente, Felício dos Santos, MG) and 2 (Pousada Rural Recanto do Vale, Fazenda São José, Diamantina, MG; Figure 1), with species being collected simultaneously during the same field trip (September 2007).

In the coastal region, G. microtarsus was captured in the Atlantic Rain Forest, in dense ombrophilous forests (Figure 5a) and in semideciduous forests (Table 1). Westwards, the specimens were sampled at Chapada Diamantina (Bahia State, $11^{\circ}-14^{\circ} \mathrm{S}$ and $41^{\circ}-43^{\circ} \mathrm{W}$ ), an area of approximately $38,000 \mathrm{~km}^{2}$, that is part of the Serra do Espinhaço, $300 \mathrm{~km}$ inland from the Atlantic Ocean (Parrini et al. 1999). It is surrounded by semiarid regions from Caatinga and Cerrado formations and presents isolated forests that can be related to the Atlantic Forest, although being considered as Dry Forest from Northeast according to Olson et al. (2001), or brejos, the typical forest remnants in the northeast Brazil (Câmara 2003). The complete Chapada Diamantina region is composed by a mixed landscape, with areas with stunded sparse forest, rupestrine grasslands, open pastures and regular forest (Silva \& Casteleti 2003). In this region, G. microtarsus was collected in a locality with deciduous seasonal forest (Figure 5b) and another one in Cerradão (Table 1, Figure 5c). Those localities outside of the Atlantic Forest here reported show that the species are not restricted to the humid forest of the coastal area of South America (Figure $5 \mathrm{~d}$ and e).

Gracilinanus agilis, a more widespread species, was recorded by us in Cerrado and Caatinga biomes, as previously reported by Costa et al. (2003). The locality in Caatinga (locality 3; Table 1) was covered by a very dense bush formation, with thorny shrubs and stunted trees (Figure 5f), as the sampling effort was carried out during the rainy season. In both localities in the Cerrado (Table 1) specimens were sampled in gallery forests. This field trip occurred during a dry season (September 2007).

Two specimens of G. agilis from two distinct localities and three of G. microtarsus of three different localities (Table 1) were karyotyped. Conventional staining showed no differences between the two species: autosomal complement showed the same diploid and autosomal number already described for both species (Carvalho et al. 2002, Pereira \& Geise 2007). Diploid number (2n) is the same (14), but autosomal number varies according to the authors. Here we follow Carvalho et al. (2002), adopting the $\mathrm{AN}=24$ : three pairs are large submetacentric (pairs 1, 2 and 3), pair 4 is a medium metacentric and pairs 5 and 6 are small submetacentric. Both X- and Y-chromosomes are also in accordance to published karyotypes, the first being a small metacentric, and the second a small acrocentric one. These results are to be expected, as marsupials present highly conserved karyotypes, and when present, geographical variation within species can only be detected through the visualization of banding patterns. Nevertheless, the data presented here are important, as they are from different localities from those described by Carvalho et al. (2002).

Measurements (Table 2) are according to those given by Costa et al. (2003), with G. agilis tail length, in both sexes, being less than $140 \mathrm{~mm}$. In G. microtarsus we observed tail length longer than the values given by Costa et al. (2003). Pelage characteristics were carefully compared with descriptions and other museum specimens, being also useful for the correct species identification made by the authors.

The occurrence of $G$. microtarsus in localities north of those previously registered (localities 7, 8, 9 and 10) follows a geographic distribution pattern observed for some widespread small mammals from the Atlantic Forest, such as Akodon cursor (Winge, 1887), Nectomys squamipes (Brants, 1827) and Metachirus nudicaudatus (É. Geoffroy, 1803) (Geise et al. 2005, 2008, Gardner 2007, Geise \& Pereira 2008).

These findings show that biome fauna endemicity suggested for mammals must be considered carefully. Gracilinanus agilis is usually described as endemic to the Cerrado/Caatinga, in opposite to G. microtarsus, which was considered 


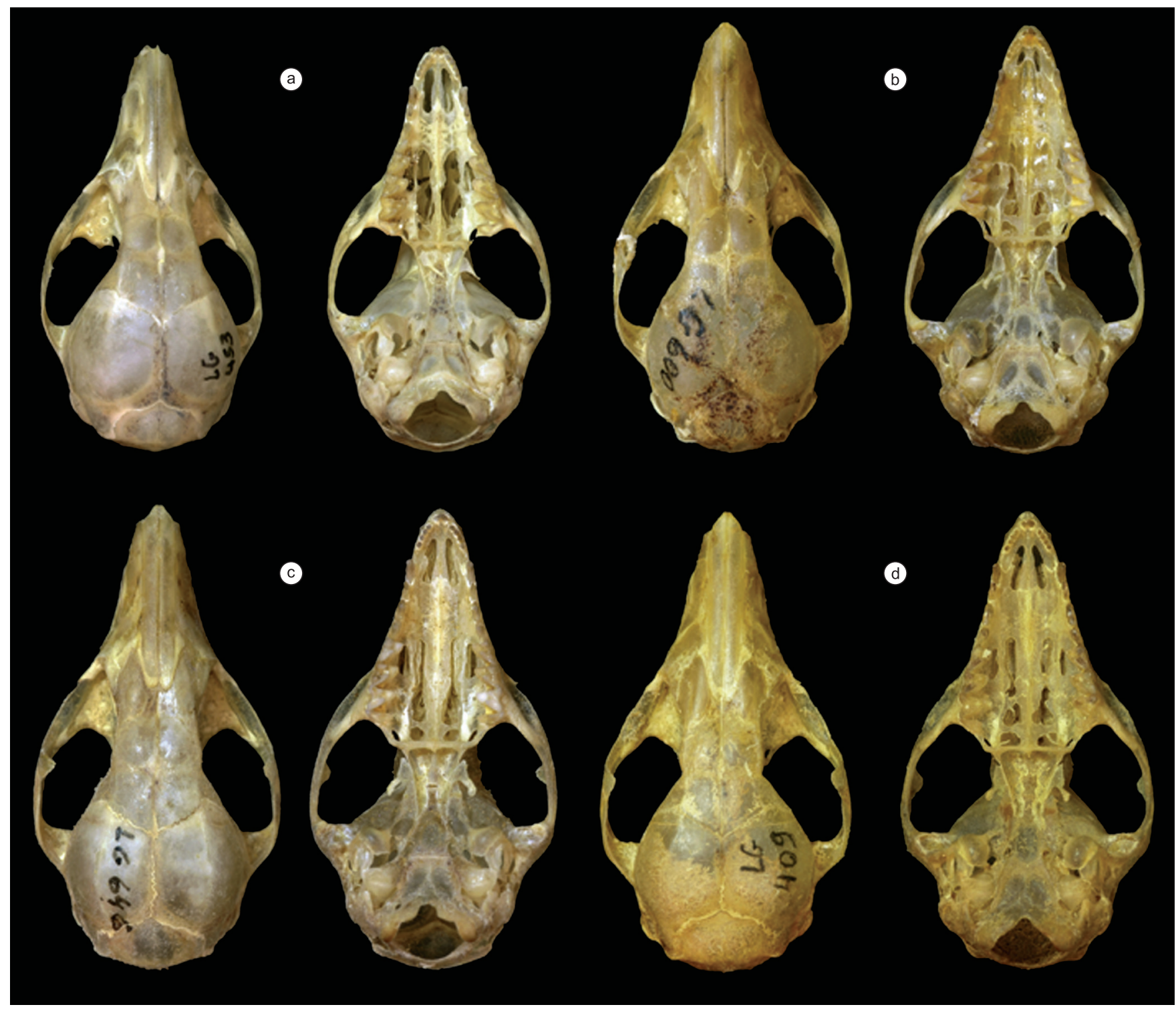

Figure 4. Dorsal and ventral views of the cranium of Gracilinanus agilis (upper specimens) and G. microtarsus (lower specimens). a) MN72689 (from Itinga, locality 3); b) MN72693 (from Felício dos Santos, locality 1); c) N72702 (from Diamantina, locality 2) and d) MN72700 (from Mucugê, locality 9). Locality numbers in parenthesis are according to Table 1.

Figura 4. Vistas dorsal e ventral do crânio de Gracilinanus agilis (espécimes superiores) e G. microtarsus (espécimes inferiores). a) MN72689 (de Itinga, localidade 3); b) MN72693 (de Felício dos Santos, localidade 1); c) MN72702 (de Diamantina, localidade 2) e d) MN72700 (de Mucugê, localidade 9). Número de localidades entre parênteses de acordo com a Tabela 1.

Table 2. Descriptive statistics (sample sizes, mean, standard deviations and range) for males and females of Gracilinanus microtarsus and G. agilis specimens. Tabela 2. Estatística descritiva (tamanho da amostra, média, desvio padrão e amplitude) para espécimes machos e fêmeas de Gracilinanus microtarsus e G. agilis.

\begin{tabular}{|c|c|c|c|c|c|c|}
\hline \multirow[t]{2}{*}{ Variable } & \multicolumn{3}{|c|}{ Males } & \multicolumn{3}{|c|}{ Females } \\
\hline & $\mathbf{N}$ & Mean (SD) & Range & $\mathbf{N}$ & Mean (SD) & Range \\
\hline \multicolumn{7}{|l|}{ G. agilis } \\
\hline HBL & 4 & $88.5(5.6)$ & $83.0-96.0$ & 4 & 86.7 (5.9) & $81.0-94.0$ \\
\hline TL & 4 & $130.5(6.5)$ & $125.0-139.0$ & 4 & $123.5(8.1)$ & $112.0-131.0$ \\
\hline Weight & 4 & $16.5(3.8)$ & $14.0-22.0$ & 4 & $17.63(3.3)$ & $14.00-21.5$ \\
\hline \multicolumn{7}{|c|}{ G. microtarsus } \\
\hline HBL & 6 & $107.8(19.3)$ & $81.0-140.0$ & 2 & $99.0(2.8)$ & $97.0-101.0$ \\
\hline TL & 6 & $156.8(10.5)$ & $139.0-167.0$ & 2 & $147.5(10.6)$ & $140.0-155.0$ \\
\hline Weight & 6 & $28.1(11.1)$ & $14.0-46.0$ & 2 & $26.00(2.8)$ & $24.0-28.0$ \\
\hline
\end{tabular}




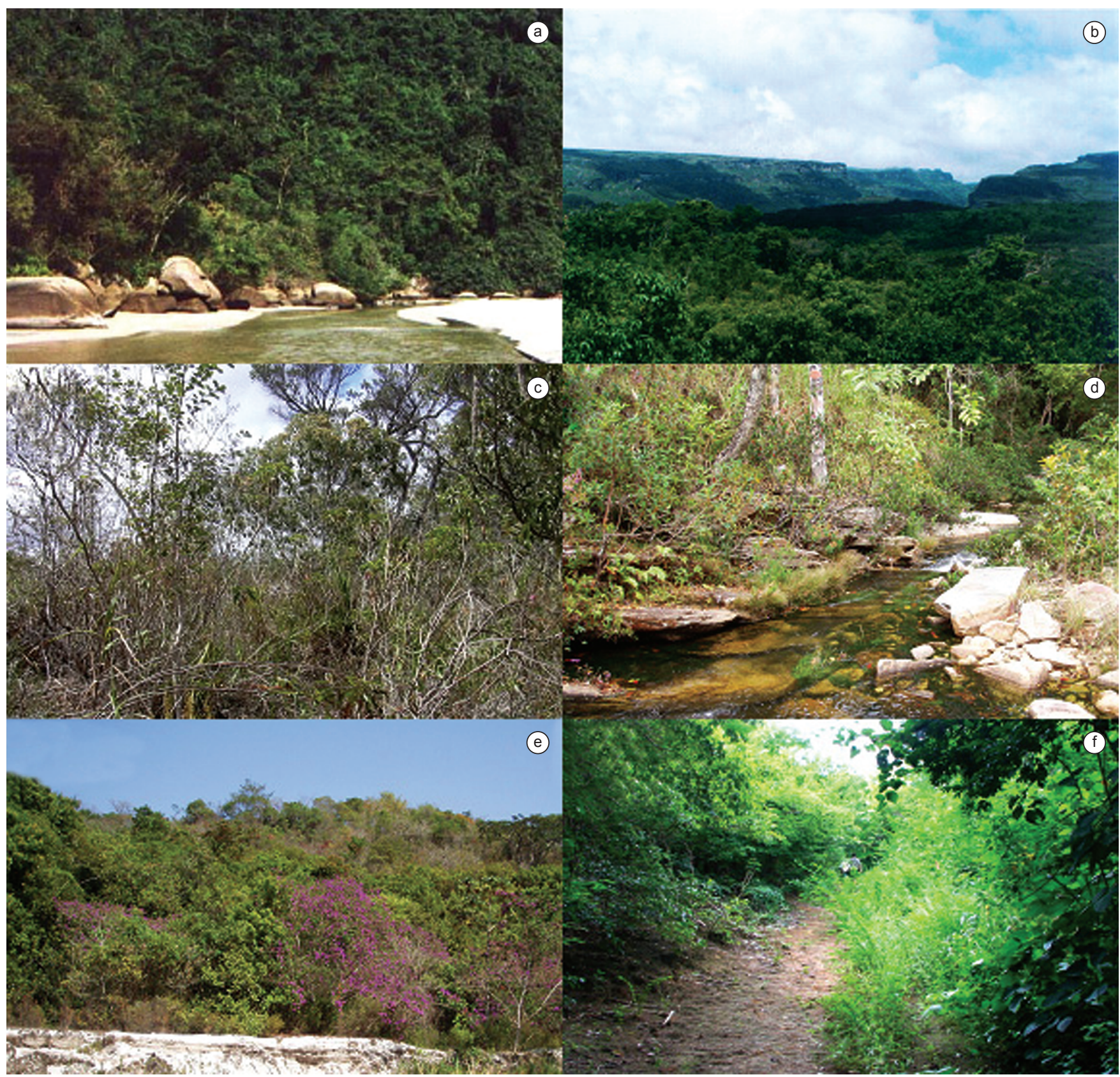

Figure 5. Representatives of some biomes and vegetation types surveyed during field work: a) Atlantic Forest - coastal forest or Atlantic Rain Forest (dense ombrophilous forests); b) Atlantic Forest (deciduous seasonal Forest); c) Cerrado - Cerradão; d and e) Cerrado - Forest formation, with gallery forests; f) Caatinga - Savana estépica, green bush formation. Photos by L. Geise.

Figura 5. Representantes de alguns biomas e tipos de vegetação amostrados durante o trabalho de campo: a) Floresta Atlântica - floresta costeira ou Floresta Úmida Atlântica (floresta ombrófila densa); b) Floresta Atlântica (floresta estacional decidual); c) Cerrado - Cerradão; d e e) Cerrado - formação florestal, com matas de galeria; f) Caatinga - Savana estépica, formação arbustiva verde. Fotos por L. Geise.

to be endemic to the Atlantic Forest (Costa et al. 2003, Brito et al. 2008). Both were found to occur in sympatry in forest formation along with gallery forests in the open Cerrado domain, a kind of forest sometimes considered to be part of Atlantic Forest domain (Câmara 2003). Such results show that a more precise interpretation of mammal species distribution is required, considering the species capability to occur in different environments. This only strengthens how little we still know the distributions patterns of most Neotropical species, even species not particularly rare as these, and how much inventory with adequate collection of voucher specimens are still needed.

\section{Acknowledgements}

Authors are grateful to L.G. Pereira, P. H. Asfora and T. Lira for the help during field activities, to L.G. Lessa and E. Hingst-Zaher for secondary specimens identification/confirmation, to L.P.C. Machado and A.T.G. Freire for the skin and crania photos. To J.L. Patton for the careful manuscript revision and to an anonymous referee and the 
editor for comments which helped to improve the manuscript. This work was supported by funds from the CNPq (Proc. 473596/2006-7). Field work was carried out with IBAMA (02001.009093/02-23 and 02001.009074/02-86) and Sisbio (14850/1) collecting permits. During this work LG received research grants from UERJ (Prociencia) and CNPq, and D.A. from FACEPE. LG is currently supported by a post-doc fellowship from CAPES.

\section{References}

BRITO, D., ASTUA DE MORAES, D., LEW, D., SORIANO, P. \& EMMONS, L. 2008. Gracilinanus agilis. In International Union for Conservation of Nature - IUCN. IUCN Red List of Threatened Species. Version 2009.1. IUCN, Switzerland. http:www.iucnredlist.org (último acesso em 18/08/2009).

CÂMARA, I.G. 2003. Brief history of conservation in the Atlantic Forest. In The Atlantic Forest of South America: biodiversity status, threats, and outlook (C. Galindo-Leal \& I.G. Câmara, eds.). Island Press, Washington, p. $31-42$.

CARMIGNOTTO, A.P. 2004. Pequenos mamíferos terrestres do Cerrado: padrões faunísticos locais e regionais. Tese de Doutorado, Universidade de São Paulo, São Paulo.

CARVALHO, B.A., OLIVEIRA, L.F.B., NUNES, A.P. \& MATTEVI, M.S. 2002. Karyotypes of nineteen marsupial species from Brazil. J. Mamm. 83(1):58-70.

COSTA, L.P., LEITE, Y.L.R. \& PATTON, J.L. 2003. Phylogeography and systematic notes on two species of gracile mouse opossums, genus Gracilinanus (Marsupialia: Didelphidae) from Brazil. Proc. Biol. Soc. Wash. 116(2):275-292.

EMMONS, L.H. \& FEER, F. 1997. Neotropical rainforest mammals: a field guide. 2 ed. University of Chicago Press, Chicago.

FERNANDEZ, F.A.S. \& PIRES, A.S. 2006. Perspectivas para a sobrevivência dos marsupiais brasileiros em fragmentos florestais: o que sabemos e que ainda precisamos saber? In Os marsupiais do Brasil: biologia, ecologia e evolução (N.C. Cáceres \& E.L.A. Monteiro-Filho, eds.). Editora da Universidade Federal de Mato Grosso do Sul, Campo Grande, p. 191-201.

FONSECA, G.A.B. \& KIERULFF, M.C.M. 1989. Biology and natural history of Brazilian Atlantic Forest mammals. Bull. Flor. St. Mus. Biol. Sc. 34(3):1-38.

GARDNER, A.L. 2007. Mammals of South America. The University of Chicago Press, Chicago. (v. 1, Marsupials, xenarthrans, shrews, and bats). xxii +198 pp.

GEISE, L., ASTÚA, D. \& SEBASTIÃO, H. 2005. Morphometric differentiation and distributional notes of three species of Akodon (Muridae, Sigmodontinae, Akodontini) in the Atlantic coastal area of Brazil. Arq. Mus. Nac. 63(1):63-74.

GEISE, L. \& PEREIRA, L.G. 2008. Rodents (Rodentia) and marsupials (Didelphimorphia) in the municipalities of Ilhéus and Pau Brasil, state of Bahia, Brazil. Check List. 4(2):174-177.
MONTEIRO-FILHO, E.L.A. \& CÁCERES, N.C. 2006. Biologia reprodutiva de fêmeas de marsupiais didelfídeos. In Os marsupiais do Brasil: biologia, ecologia e evolução (N.C. Cáceres \& E.L.A. Monteiro-Filho, eds.). Editora da Universidade Federal de Mato Grosso do Sul, Campo Grande, p. 99-110.

MORELLATO, L.P.C. \& HADDAD, C.F.B. 2000. Introduction: the Brazilian Atlantic Forest. Biotr. 32(4b): 786-792.

OLSON, D.M, DINERSTEIN, E., WIKRAMANAYAKE, E.D., BURGESS, N.D., POWELL, G.V.N., UNDERWOOD, E.C., D’AMICO, J.A., ITOUA, I., STRAND, H.E., MORRISON, J.C., LOUCKS, C.J., ALLNUTT, T.F., RICKETTS, T.H., KURA, Y., LAMOREUX, J.F., WETTENGEL, W.W., HEDAO, P. \& KASSEM, K.R. 2001. Terrestrial ecoregions of the World: a new map of life on Earth. BioScience. 51(11): 933-938.

PARDINI, R. 2004. Effects of forest fragmentation on small mammals in an Atlantic Forest landscape. Biodivers Conserv. 13:2567-2586.

PARRINI, R., RAPOSO, M.A., PACHECO, J.F., CARVALHÃES, A.M.P., MELO Jr., T.A., FONSECA, S.M. \& MINNS, J.C. 1999. Birds of the Chapada Diamantina, Bahia, Brazil. Cotinga. 11:86-95.

PATTON, J.L. \& COSTA, L.P. 2003. Molecular phylogeography and species limits in rainforest Didelphid marsupials of South America. In Predators with pouches: the biology of carnivorous marsupials (M. John, C. Dickman \& M. Archer, eds.). Csiro Publishing, Collingwood, Australia, p. 63-81.

PEREIRA, L.G. \& GEISE, L. 2007. Karyotype composition of some rodents and marsupials from Chapada Diamantina (Bahia, Brazil). Braz. Jour. Biol. 67(3):509-518.

SANTORI, R.T. \& ASTUA DE MORAES, D. 2006. Alimentação, nutrição e adaptações alimentares de marsupiais brasileiros. In Os marsupiais do Brasil: biologia, ecologia e evolução (N.C. Cáceres \& E.L.A. Monteiro-Filho, eds.). Editora da Universidade Federal de Mato Grosso do Sul, Campo Grande, p. 241-254.

SILVA, J.M.C. \& CASTELETI, C.H.M. 2003. Status of the biodiversity of the Atlantic Forest of Brazil. In The Atlantic Forest of South America: biodiversity status, threats, and outlook (C.Galindo-Leal \& I.G. Câmara, eds.). Island Press, Washington, p. 43-59.

VIEIRA, E.M. 2006. Padrões de uso vertical do hábitat por marsupiais brasileiros. In Os marsupiais do Brasil: biologia, ecologia e evolução (N.C. Cáceres \& E.L.A. Monteiro-Filho,eds.). Editora da Universidade Federal de Mato Grosso do Sul, Campo Grande, p. 217-228.

VOSS, R.S. \& JANSA, S.A. 2009. Phylogenetic relationships and classification of didelphid marsupials, an extant radiation of New World metatherian mammals. Bull. Am. Mus. Nat. Hist. 322:1-177.

Received: 30/04/09

Revised: 17/09/09

Accepted: 09/11/09 